\title{
Article
}

\section{Evaluation and Suggestions for Rational Energy Tax Policy in South Korea}

\author{
Kap Soon Kim¹, Sung Man Yoon ${ }^{2, *}$ \\ 1 School of Business, Dongguk University (Seoul), 30, Pildong-ro 1-gil, Jung-gu, 04620 Seoul, Korea; \\ kks@dongguk.edu \\ 2 Department of Business Administration, Seoul National University of Science and Technology, 232 \\ Kongneung-ro, Nowon-gu, 01811 Seoul, Korea; ysm6123@seoultech.ac.kr \\ * Correspondence: ysm6123@seoultech.ac.kr
}

\begin{abstract}
Energy taxation is used globally as a means of energy policy. Energy tax plays an important role as a driving force for the conversion to environmentally friendly energy. The basic tax principles considered in the design of energy taxation increases the efficiency of policy instruments. The purpose of this study is to evaluate South Korea's energy taxation based on tax principles, namely, equity, efficiency, simplicity, flexibility, and accountability and suggest directions for improvement. This study applied a methodology that provides policy implications, such as reviewing existing literature and comparing energy taxes. Results of this study show that South Korea's energy taxation is negative in terms of equity, simplicity, and accountability. South Korea's current energy tax is regressive to income classes and complex tax structures and it does not objectively measure the impact of energy taxation. However, energy taxation is evaluated positively in terms of efficiency and flexibility because it meets the greenhouse gas reduction policy and operates a flexible tax rate. The results of this analysis provide policy implications for reorganizing South Korea's energy taxation.
\end{abstract}

Keywords: energy tax; tax principles; energy policy; equity; efficiency; simplicity; flexibility; accountability.

\section{Introduction}

Public interest in energy conversion has increased in South Korea with the accelerating global transition to eco-friendly energy [1,2]. Germany, which enacted the Renewable Energy Act in 2000, formulated the energy conversion policy in 2010 when energy conversion became a global issue. Energy conversion is a structural change in the energy supply and demand system over a long period of time. This development has shown a structural change from $6.2 \%$ in 2000 to $30.4 \%$ in 2015 [2]. South Korea announced an energy conversion roadmap, which includes nuclear power-related issues. Energy conversion has a large impact on people's quality of life, as well as on the economic industry; thus, the spread of a national consensus should be preceded [3].

However, this energy conversion policy is inferior in terms of the effectiveness because the proportion of coal-fired power generation has recently increased. That is, the externalities, such as environmental costs and the measures to reduce particulate matter, do not meet the national expectations, and a detailed implementation plan for greenhouse gas (GHG) reduction is lacking [4]. The rationalization of energy taxation as a means is strongly required for the active implementation of such energy conversion.

Numerous countries have been using various energy taxes and charges (hereafter referred to as "energy tax"”) to induce energy conversion [5]. Generally, energy taxation has a multilevel impact on the national economy. Energy production and consumption patterns not only influence the paradigm of the domestic economy but also create economic efficiency and market competition 
$[5,6]$. Moreover, energy taxation is a means to stimulate green economic development and technologies to reduce GHG emissions.

However, the South Korean government has changed energy taxation to a higher frequency depending on environmental problems and domestic and global economic conditions. In addition, South Korea has introduced energy taxation, which is composed of diverse and complicated specifications, as a form of differential taxation for energy sources. However, the South Korean government revises its energy taxation annually for new energy policies, which fail to reflect the application of basic tax principles adequately [7]. Generally, if energy taxation is not based on theoretically organized tax principles, it may be inefficient to achieve the objectives of the energy policy and reduce the social acceptability level of the energy tax $[7,8]$.

Therefore, this study aims to evaluate the current energy tax system of South Korea from the viewpoint of tax principles and suggest directions for future energy tax reforms based on the evaluation results. Tax principles have been systematized by Smith[9]'s basic theory and by various studies on tax principles. The present study evaluates South Korea's energy taxation based on equity, efficiency, simplicity, flexibility, and accountability.

This study provides suggestions on the directions of rational energy tax reforms by reexamining energy taxation from various points, such as tax policy, energy source, sector and social acceptance. Furthermore, this study provides policy implications for the future design of energy tax as a means of South Korean energy policy. The remainder of this study is organized as follows. Section 2 presents the theoretical background and the South Korean energy taxation; Section 3 presents the evaluation of energy taxation based on tax principles; Section 4 provides suggestions for rational energy taxation in South Korea. Finally, Section 5 discusses the study results and their implications and provides policy recommendations.

\section{Theoretical Background and Energy Taxation in South Korea}

\subsection{Theoretical Background of Tax Principles}

The origin of the tax principle is derived from Smith [9] and his concept of equity, certainty, convenience, and economy, which have been added on or reduced by various studies. Taxation should reflect general tax principles, such as legality, equality, legal certainty and legitimate expectation, fair play, public trust in tax administration, good faith, transparency, proportionality, non-retroactivity, and estoppel [10]. As a representative study of tax principles, Alice and Bentley [11] combined the OECD principles (application of the principles) and the AICPA principles (Ten Principles of Good Tax Policy Related to New Zealand) with respect to equity and fairness, certainty and simplicity, and effectiveness.

These general tax principles can be applied to various time types; however, a few studies have proposed the legal principles for energy taxation. Burgers and Weishaar [7] emphasized transparency as a principle of energy taxation. Energy taxation should be clear on who is taxable (the taxable subject, which is also referred as the taxpayer), what is taxed (the tax base), what exemptions are provided (tax incentives), and what the costs are to the polluters per unit of pollution generated (tax rate). Payers of energy tax should not be confronted with uncertainties and the amount they should pay. Furthermore, the energy design and execution should be proportional to what taxpayers consider a fair amount; that is, taxes are not excessive, and taxpayers are not confronted with high compliance costs.

Studies on energy tax have focused on individual factors rather than on comprehensive tax principles, and most studies emphasize the equity side of energy tax. Most studies suggest that energy tax is regressive. José et al. [9] analyzed the impact of socioeconomic factors on the degree of poverty on the premise that equality and efficiency are principles to be met by energy tax and suggested that energy tax is weak in equity. The authors also suggested that the poor pay more energy-related taxes than the rich [10-12]. 
William [13] measured the equity of energy tax by energy source and argued that low-income households use motorcycles or bicycles rather than cars; thus, residential heating fuels are relatively lower in vertical equity than transport fuels. The study also emphasized that among heating fuels, electricity is the most vulnerable to vertical equity.

In sum, the tax principles presented by Smith [14], OECD, AICPA, Romano [15], Alley and Bentley [16], and William [13] can be summarized as equity, efficiency, simplicity, flexibility, and accountability.

- Equity: A desirable tax system distributes tax burden fairly among taxpayers (people). Fairness exists when equitable distribution is made among taxpayers [10,11]. Finally, taxes are basically the means by which the nation bears the costs of the work undertaken by the state; thus, the requirement that tax burden be distributed equally is of considerable importance.

- Efficiency: Tax levitation affects the decisions of the private sector and leads to resource allocation inefficiency and distortion. Therefore, being a desirable tax system necessitates disturbances in the resource allocation process to be minimized to reduce the loss of efficiency [9].

- Simplicity: No matter how equitable and efficient a tax system is, such system is undesirable if it is highly complicated, difficult to understand, or extremely costly. Simple taxation is an important condition not only in terms of reducing the cost of tax administration but also in terms of the voluntary compliance of taxpayers. If the tax system is complicated, then obtaining the principle of flexibility would be difficult.

- Flexibility: Tax system should be sufficiently flexible to respond to changes in economic and market conditions and government policies. For example, if the tax system is flexible, then the government can easily achieve a specific policy goal by means of taxation. Therefore, a rigid tax system is undesirable and cannot cope with rapidly changing economic situations.

- Accountability: Responsible governments should clearly state how much each taxpayer is willing to pay and allow them freedom of choice on consumptions, behaviors, and transactions. The government should be designed to avoid unreasonable taxation on taxpayers who lack information to achieve a desirable energy taxation system. Therefore, the government is politically irresponsible because it tends to avoid taxpayers' reactions by using indirect taxes, such as consumption tax. Different from income tax, which is a direct tax, the amount of the main means of financing is unknown because taxpayers do not generally calculate the amount of tax they are willing to pay before any transaction. A responsible government should also seek public consent after clearly describing who collects the taxes and the amount and purpose of tax.

In applying these tax principles to energy tax, a reasonable energy tax can be devised only if the following are considered:

- Corrective function and economic efficiency for environmental pollution reduction: The impact of taxation on the economic activities of private sectors does not only imply negative effects. If taxes can play a role in complementing and preventing market failures, then taxation positively affects the economy of the private sectors. The energy tax imposed to encourage the public to save energy or change their preferences among energy sources is a type of corrective tax (e.g., Pigouvian tax). However, inducing people to make energy consumption choices through taxes conflicts with the principle of consumer sovereignty. The principle of consumer sovereignty indicates that if a sufficient reason to change the energy consumption choice exists, then the government does not need to engage in it because it is the consumers who save money or change their preferences. Even high-income households with high-energy consumption levels may legitimize their energy consumption choices because they use energy at the expense of taxes.

- Tradeoff among efficiency, equity, and simplicity: In terms of efficiency, even an impeccably clean energy taxation cannot be a desirable tax system if it results in high inequity among income classes. Although environmental policy through energy taxation has the advantage of 
mitigating the inefficiency and distortion of resource allocation by externalities to some extent, satisfying equity in distribution simultaneously is difficult. The changes in energy tax result in the increase of the direct burden of low-income households due to the increase in the price of products or certain energy sources (e.g., gasoline, light oil, electricity, and gas); this increase is due to the cost pressures decreasing the actual income of low-income households. In this case, low-income households have to bear the environmental cost. In addition, the tax system becomes increasingly complex when achieving efficiency, equity, and policy objectives.

\subsection{Energy Taxation in South Korea}

\subsubsection{Transportation Energy Taxation}

In South Korea, the transportation-energy-environmental (TEE) tax is levied at $529 \mathrm{KRW} / \mathrm{L}$ and $375 \mathrm{KRW} / \mathrm{L}$ for diesel and gasoline, respectively. It also accounts for the largest portion of diesel- and gasoline-related taxes and charges. This tax was initially levied on the basis of the Transportation Tax Act. However, it was converted into the current TEE tax in early 2009 because of the operational rigidity of the target taxation system and the complexity of the taxation system for oil. In the case of the TEE tax, the flexible tax rate within $\pm 30 \%$ of the basic tax rate can be specified to cope flexibly with fluctuations in global oil prices; however, it has constantly applied the positive flexible tax rate since the period of high oil prices in 2009.

Individual consumption (IC) tax is also imposed on NPG for $275 \mathrm{KRW} / \mathrm{kg}$, which is $23 \mathrm{KRW} / \mathrm{kg}$ higher than the basic IC tax of $252 \mathrm{KRW} / \mathrm{kg}$ for butane used for transportation. IC tax charges 14 $\mathrm{KRW} / \mathrm{kg}$ for propane, which is used for residential and commercial purposes; this amount is 6 $\mathrm{KRW} / \mathrm{kg}$ less than the basic IC tax of $20 \mathrm{KRW} / \mathrm{kg}$. Particularly, the education tax for butane is imposed $15 \%$ of the consumption tax, and various charges are imposed.

In the case of CNG, IC tax, such as LNG, is charged at only $42 \mathrm{KRW} / \mathrm{kg}$ in addition to sales charges in consideration of its special nature of being used as transportation fuel. Therefore, South Korea's CNG tax is significantly lower than the minimum amount of $207.48 \mathrm{KRW} / \mathrm{kg}$, as specified in the EU Energy Guidelines [17]. Previously, gas subsidies were provided to buses except for those using CNG. However, since July 2017, gas subsidies of up to $67.25 \mathrm{KRW} / \mathrm{kg}$ have also been provided for CNG buses.

\subsubsection{Generation Energy Taxation}

The South Korean government included bituminous coal for power generation in the IC tax to mitigate the excessive consumption of energy demands due to the relative price differences between electricity and other types of energy. Moreover, the tax burden level on alternative fuels, such as LNG, kerosene, and propane, was lowered to distribute electricity consumption to other types of energy. As a result, the IC tax for LNG in 2014 is reduced from $60 \mathrm{KRW} / \mathrm{kg}$ to $42 \mathrm{KRW} / \mathrm{kg}$ [18]. However, the IC tax for LNG for residential, commercial, and power cogeneration has been maintained to alleviate the burden on ordinary people. However, in July 2015, the IC tax for LNG power generation was again substantially increased from $42 \mathrm{KRW} / \mathrm{kg}$ to $60 \mathrm{KRW} / \mathrm{kg}$. Therefore, LNG is currently being charged and taxed a total of $96.2 \mathrm{KRW} / \mathrm{kg}$, which includes IC tax, import levy, safety management charge, and tariff of $60,24.2,4.8$, and $7.2 \mathrm{KRW} / \mathrm{kg}$, respectively. With regard to energy for power generation, $91.4 \mathrm{KRW} / \mathrm{kg}$ is exempted from the safety management charge of $4.8 \mathrm{KRW} / \mathrm{kg}$, and starting April 2019, $23 \mathrm{KRW} / \mathrm{kg}$ will be reduced by $68.4 \mathrm{KRW} / \mathrm{kg}$.

Flexible tax rate was temporarily applied to bituminous coal, with $19 \mathrm{KRW} / \mathrm{kg}$ for high-calorific bituminous coal and $17 \mathrm{KRW} / \mathrm{kg}$ for low-calorific bituminous coal. The price of international bituminous coal has stabilized downward, a year has passed since the inception of tax reform; thus, the application of the flexible tax rate has ceased since July 2015, and $24 \mathrm{KRW} / \mathrm{kg}$ and $22 \mathrm{KRW} / \mathrm{kg}$ have been applied for high- and low-calorific bituminous coals, respectively. The South Korean government changed the second-step tax rate into the differential tax rate of the third step 
(high-mid-low-calorific bituminous coals), and their tax rates were adjusted to 27, 24, and 21 $\mathrm{KRW} / \mathrm{kg}$, respectively; this policy was implemented to streamline the relative price system by calorific value, such as the problem of high-calorific bituminous coal after-tax prices being relatively lower than the after-tax price of low-calorific bituminous coal [3]. In April 2017, tax rates were increased by $6 \mathrm{KRW} / \mathrm{kg}$. This increase was applied as 33, 30, and $27 \mathrm{KRW} / \mathrm{kg}$ for high-, mid-, and low-calorific bituminous coals, which were later increased to $39 \mathrm{KRW} / \mathrm{kg}$ and $33 \mathrm{KRW} / \mathrm{kg}$ in April 2018 and $46 \mathrm{KRW} / \mathrm{kg}$ in 2019, respectively.

\subsubsection{Energy Tax Reform in 2018}

By 2018, the government imposed an IC tax of $36 \mathrm{KRW} / \mathrm{kg}$ on bituminous coal without imposing import duties or tariffs. However, this amount was raised to $46 \mathrm{KRW} / \mathrm{kg}$ to rationalize the taxes and the charge system for power generation fuels (bituminous coal and LNG), thereby reflecting the environmental cost of particulate matters. The LNG also imposes the tax burden items of $91.4 \mathrm{KRW} / \mathrm{kg}$, which has the current ratio of 7:3, to become $23 \mathrm{KRW} / \mathrm{kg}$. Moreover, the IC tax and import levy of $60 \mathrm{KRW} / \mathrm{kg}$ and $24.2 \mathrm{KRW} / \mathrm{kg}$ are reduced to $12 \mathrm{KRW} / \mathrm{kg}$ and $3.8 \mathrm{KRW} / \mathrm{kg}$, respectively. This rate will apply to declared export and import items starting April 2019.

The TEE tax, which was set to be maintained until the end of 2018, was extended until the end of 2021 to secure stable investment resources for transportation facilities, environmental improvements, and balanced national developments. The TEE tax will then be converted into an IC tax. The South Korean government extended the deadline for applying the IC tax exemption for hybrid vehicles from the end of 2018 to the end of 2021 to expand the supply of eco-friendly vehicles. In addition, the government extended the value added tax (VAT) exemption for CNG buses from the end of 2018 to the end of 2021 to support the supply of environmentally friendly natural gas buses.

\section{Evaluation of Energy Tax Policy in South Korea}

This study evaluates the current energy tax policy of South Korea and makes several suggestions on the rational direction for reform. First, this study seeks to evaluate South Korea's current energy taxation from the perspective of tax principles, namely, equity, efficiency, simplicity, flexibility, and accountability.

\subsection{Equity}

Even if the current energy taxation is compared with the proportional taxation standard for each energy source, evaluating how small the burden on the low-income class is compared with the that on the high-income class is difficult to perform objectively. However, in view of the tax burden level of the low-income class in the process of energy tax reform, efforts to alleviate it are necessary and important. The vertical equity of the tax burden is important; however, effective environmental policies, such as the conversion to environmentally friendly energy, cannot succeed without the support of the low-income class.

Figure 1 presents the tax revenues and (social security) contribution-to-GDP ratio and tax revenue-to-GDP ratio of OECD member countries. The average tax revenues and contribution-to-GDP ratio of OECD member countries has increased steadily since 2010, and the increase was $34.2 \%$ in 2016. South Korea's tax revenues and contribution-to-GDP ratio was $26.3 \%$ in 2016, ranking 28th out of 33 countries. This ranking rose $4.6 \%$ from the previous year, which was $12.5 \%$ higher than in 2010. In addition, the tax revenue-to-GDP ratio of OECD member countries has continuously increased since 2010, and the average tax revenue-to-GDP ratio in 2016 was approximately $25.2 \%$. The tax revenue-to-GDP ratio in South Korea was $19.4 \%$, which is similar to the Czech Republic, slightly lower than the US (19.8\%), and up 5.2\% from the previous year. 


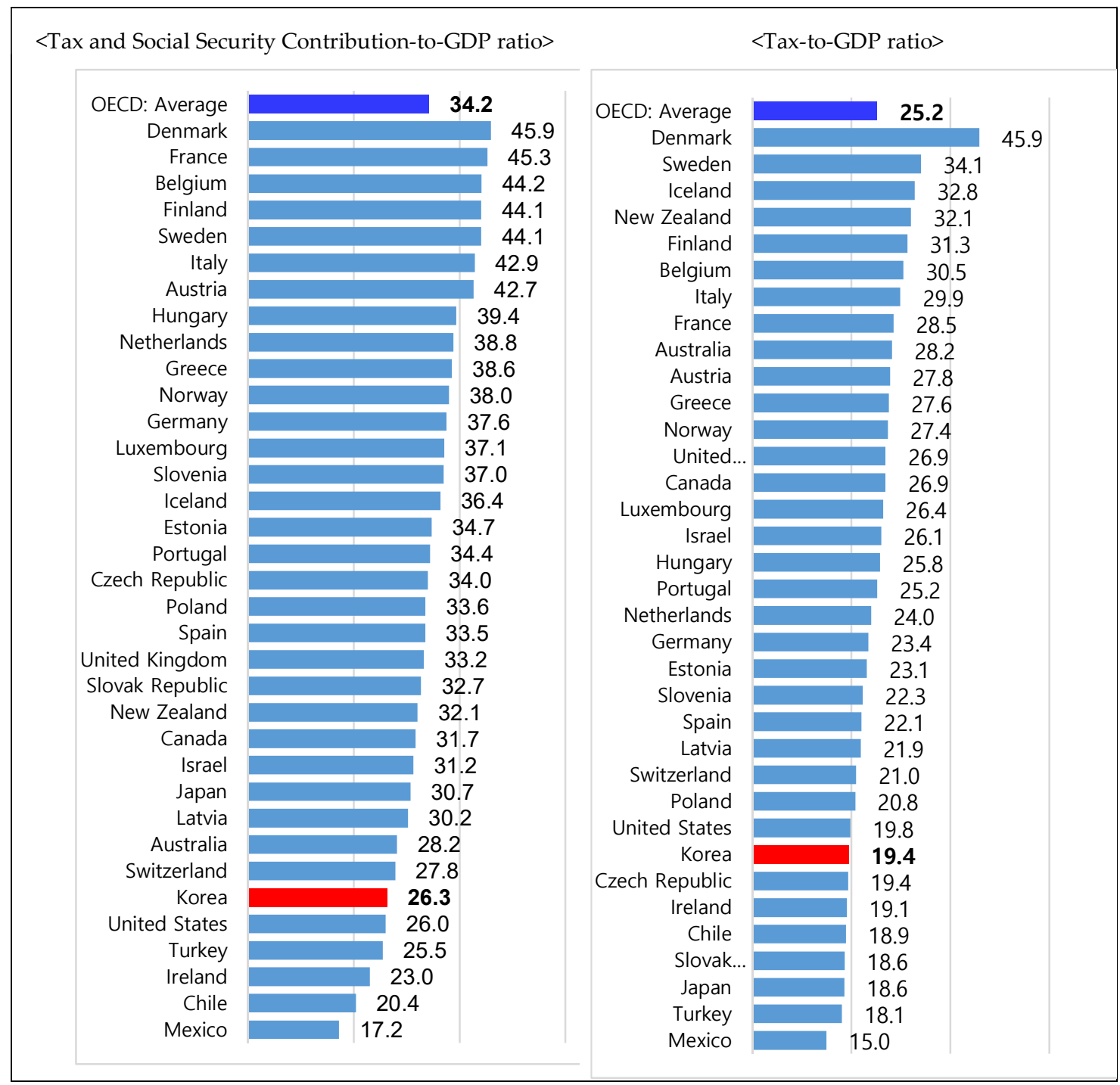

Figure 1. OECD countries' Tax and Social Security Contribution-to-GDP and Tax-to-GDP ratio (\%).

The average VAT revenue-to-GDP ratio for OECD member countries was $6.8 \%$ in $2000,6.6 \%$ in 2011, and 7.0\% in 2016, indicating a steady upward trend. However, South Korea's VAT revenue-to-GDP ratio was 4.2\% in 2016, ranking 29th among 33 countries (excluding Australia and Greece), $3.7 \%$ in 1980, and $4.3 \%$ in 2012. In addition, the average excise tax revenue-to-GDP ratio of OECD member countries increased from $2.9 \%$ in 1980 to $2.9 \%$ in 2000, and $2.7 \%$ in 2010, and $2.6 \%$ in 2016. However, South Korea's was 2.1\% in 2016, which ranked 23rd among 32 countries (excluding Australia, Mexico, and Greece) and was similar to Germany and Ireland. South Korea's average excise tax revenue-to-GDP ratio fell from $2.6 \%$ in 1980 to $2.1 \%$ in 2012 and $2.1 \%$ in 2016.

Different from the trend of general taxes, the average environment-related tax-to-GDP ratio of OECD member countries representing energy taxes was $8.8 \%$ in 2014, slightly increased to $9.0 \%$ in 1980, but decreased again after 2000. However, South Korea's environment-related tax-to-GDP ratio was $14.1 \%$ in 2014, which was higher than the OECD average of $9.1 \%$ and the fourth highest among the OECD member countries. Among the OECD member countries, Turkey (18.6\%), Slovenia $(17.5 \%)$, the Netherlands $(14.7 \%)$, and the Czech Republic $(14.1 \%)$ had the highest environmental-related tax-to-GDP ratio. The countries with the lowest ratios were Mexico $(0.5 \%)$, the US (3.7\%), New Zealand (4.2\%), and Canada (4.3\%). 
South Korea had the highest environment-related tax revenue-to-GDP ratio among major economies. The comparison of environment-related tax revenues based on PPP in 2010, the US had the highest at $\$ 112,282$ million in 2014 , followed by Italy at $\$ 72,237$ million, Germany at $\$ 68,418$ million, and South Korea at $\$ 44,065$ million.

South Korea's tax revenue and contribution-to-GDP ratio and tax revenue-to-GDP ratio were lower than the averages of OECD member countries. However, its environment-related tax revenue-to-GDP ratio was higher than the OECD average. In other words, its environment-related tax revenue-to-GDP ratio was $2.54 \%$, which is $1.61 \%$ on average for OECD member countries. South Korea's tax revenue was $14.14 \%$, which is higher than the OECD average of $8.81 \%$. Therefore, South Korea is highly burdened by indirect and environment-related taxes. The burden of the low-income class is expected to be relatively high because the proportion of the total tax revenue is also high.

Table 1. OECD member countries' average and Korea's comparison.

\begin{tabular}{l|c|c}
\hline & OECD Average & South Korea \\
\hline Tax Rev. and Contribution-to-GDP (FY2016) & $34.2 \%$ & $26.3 \%$ \\
\hline Tax Rev.-to-GDP (FY2016) & $25.2 \%$ & $19.4 \%$ \\
\hline Excise Tax Rev.-to-GDP (FY2016) & $2.62 \%$ & $2.13 \%$ \\
\hline Environmentally related Tax Rev.-to-GDP (FY2016) & $1.61 \%$ & $2.54 \%$ \\
\hline National Tax Rev.-to-Total Tax Rev. (FY2015) & $79.52 \%$ & $75.41 \%$ \\
\hline Direct Tax Rev.-to-Total Tax Rev. (FY2015) & $48.52 \%$ & $46.10 \%$ \\
\hline Excise Tax Rev.-to-Total Tax Rev. (FY2015) & $10.60 \%$ & $11.01 \%$ \\
\hline Environmentally related Tax Rev.-to-Total Tax Rev. (FY2015) & $8.81 \%$ & $14.14 \%$ \\
\hline Increase ratio in Environmentally related Tax Rev. based on & $12.83 \%$ & $79.53 \%$ \\
\hline PPP in 2010 compared to 2000 & & \\
\hline
\end{tabular}

Figure 2 presents the tax-to-price ratios of fuel for transportation and electricity. The tax-to-price ratio of non-commercial vehicle diesel in OECD member countries was $49.5 \%$ by consumer price in 2017, unleaded gasoline was 42.1\%, and non-commercial vehicle LPG was 31.8\%. Meanwhile, South Korea's tax-to-price ratios for non-commercial gasoline, unleaded gasoline, and non-commercial vehicle LPG were 59.1\%,50.3\%, and 35.8\%, respectively, which are higher than the OECD average (excluding South Korea). However, the tax-to-price ratio of electricity for industrial and residential use was $3.6 \%$ and $12 \%$, respectively, which is considerably lower than the OECD averages (excluding South Korea) of $16.4 \%$ and $27.4 \%$, respectively. As a result, the tax-to-price ratio of fuel for transportation is higher than the OECD average, and that of electricity is considerably lower than the OECD average.

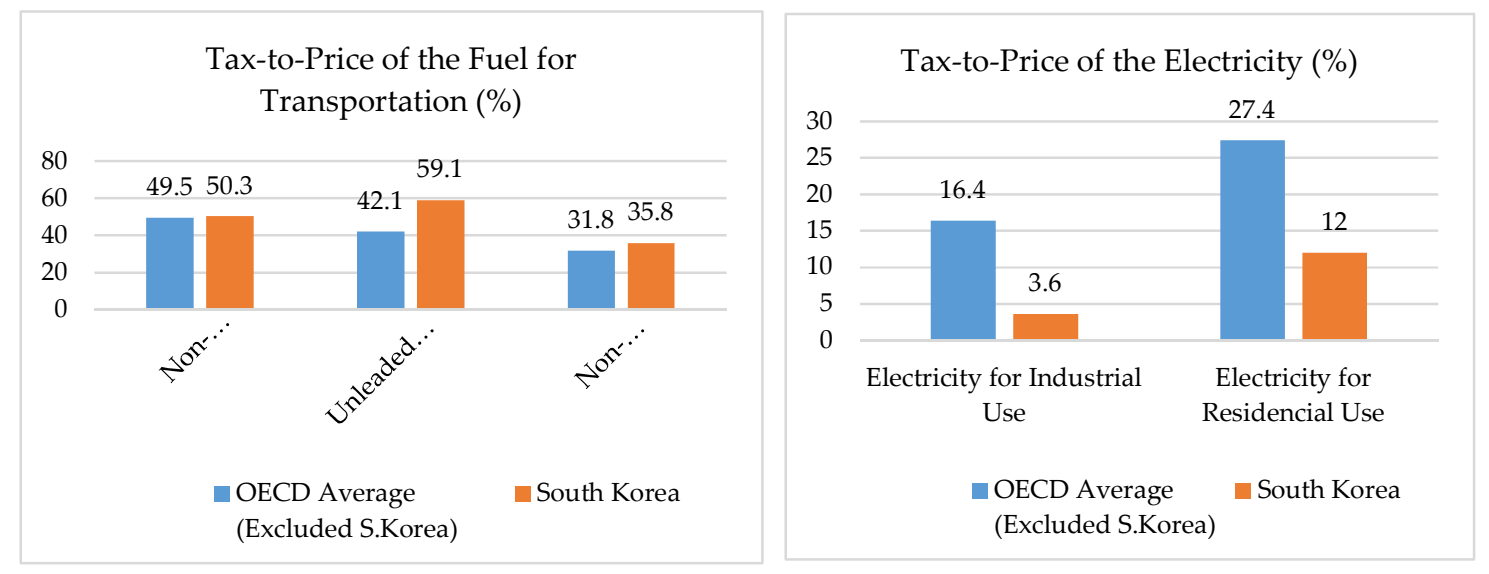

Figure 2. tax-to-price ratio of the fuel for transportation and electricity. 
From the perspective of equity in South Korea, energy tax rates for transportation diesel and gasoline are generally higher than those for OECD member countries, and the structure of inverse nature is shown by income level. With regard to oil other than transportation oil, the oil tax for heating is slightly inversed, and the tax on electric power is analyzed to be inversed [19].

\subsection{Efficiency}

South Korea's energy policy principles are as follows: (a) the reduction of the use of fossil fuels, such as petroleum and coal, and the improvement of energy self-reliance; (b) the prevention of global warming and environmental conservation through the strengthening of energy demand management; (c) the diversification of renewable energy; (d) the creation of new markets through the introduction of competition factors in the energy industry market; (e) the expansion of welfare related to energy, such as expansion of benefits to low-income households; and (f) the strengthening of energy security by securing resources abroad and diversifying imports.

Accordingly, the South Korean government distinguishes the use of energy for transportation and power generation and imposes differential taxation. For transport energy, gasoline and diesel-related tax revenues account for more than $90 \%$ of the total energy-related consumption tax. However, gasoline and diesel consumptions account for less than $15 \%$ of the total energy consumption, and the ratio of tax revenues to their consumption is extremely high. The TEE tax (529 KRW/L for gasoline and $375 \mathrm{KRW} / \mathrm{L}$ for diesel), which constitutes the largest portion of gasoline- and diesel-related taxes and charges, continues to be maintained (e.g., currently extended to 2021). In addition, taxes on various items, such as tariff, education tax, regional motor fuel tax, and VAT, are imposed. In the case of diesel, oil price subsidies for lorries are supported within certain limits.

In addition, since the second energy tax reform in 2005, the South Korean government has maintained the tendency to adjust the relative price ratio of gasoline, light oil, and LPG to 100:85:50. An IC tax of $275 \mathrm{KRW} / \mathrm{kg}$ is applied to butane gas used mainly for transportation. Propane gas for home and commercial use is subject to $14 \mathrm{KRW} / \mathrm{kg}$ IC tax. CNG is used for public transportation; thus, similar to LNG, only an IC tax of $42 \mathrm{KRW} / \mathrm{kg}$ is applied. The oil price subsidy, which only applied to buses, has also been applied to CNG buses in 2017.

In power generation, the IC tax was reduced from $60 \mathrm{KRW} / \mathrm{kg}$ to $42 \mathrm{KRW} / \mathrm{kg}$ in 2014 and then increased to $60 \mathrm{KRW} / \mathrm{kg}$ in 2015 (current tariff and import charges totaling $90.8 \mathrm{KRW} / \mathrm{kg}$ ) to promote LNG consumption as an alternative to electricity. In addition, an IC tax of 17-19 KRW/kg was implemented for bituminous coal for power generation. Bituminous coal for power generation was not previously taxed despite its large amount of GHG and particulate matter emissions. An IC tax of 33-39 KRW/kg was imposed in April 2018. In 2019, the LNG taxes and charges were reduced from $90.8 \mathrm{KRW} / \mathrm{kg}$ to $23 \mathrm{KRW} / \mathrm{kg}$, and the IC tax for bituminous coal for power generation was increased from $36 \mathrm{KRW} / \mathrm{kg}$ to $46 \mathrm{KRW} / \mathrm{kg}$.

\subsection{Simplicity}

South Korea's complicated energy regulation body consists of six types of taxes and five types of charges. Tariffs, TEE taxes, IC taxes, education taxes, VATs exist as national tax, and regional motor fuel taxes (automobile tax) as local tax. Import, sales, safety management, and quality inspection charges, as well as power industry-based funds as charges, also exist. TEE and education taxes are specific taxes; thus, TEE tax is used for the expansion of transportation facilities and public transportation, energy and resource-related projects, and the conservation and improvement of the environment; whereas education tax is used as a financial resource for educational finances.

Taxpayers' continued tax burden on energy use has increased with the total tax revenue due to increased GDP. By strengthening energy taxation annually since 2008, the energy taxation 
complexity and the people's taxes have likewise increased. As shown in the Figure 3, the TEE tax accounts for approximately $60 \%$ of the total energy tax revenues (inclusive of all charges).

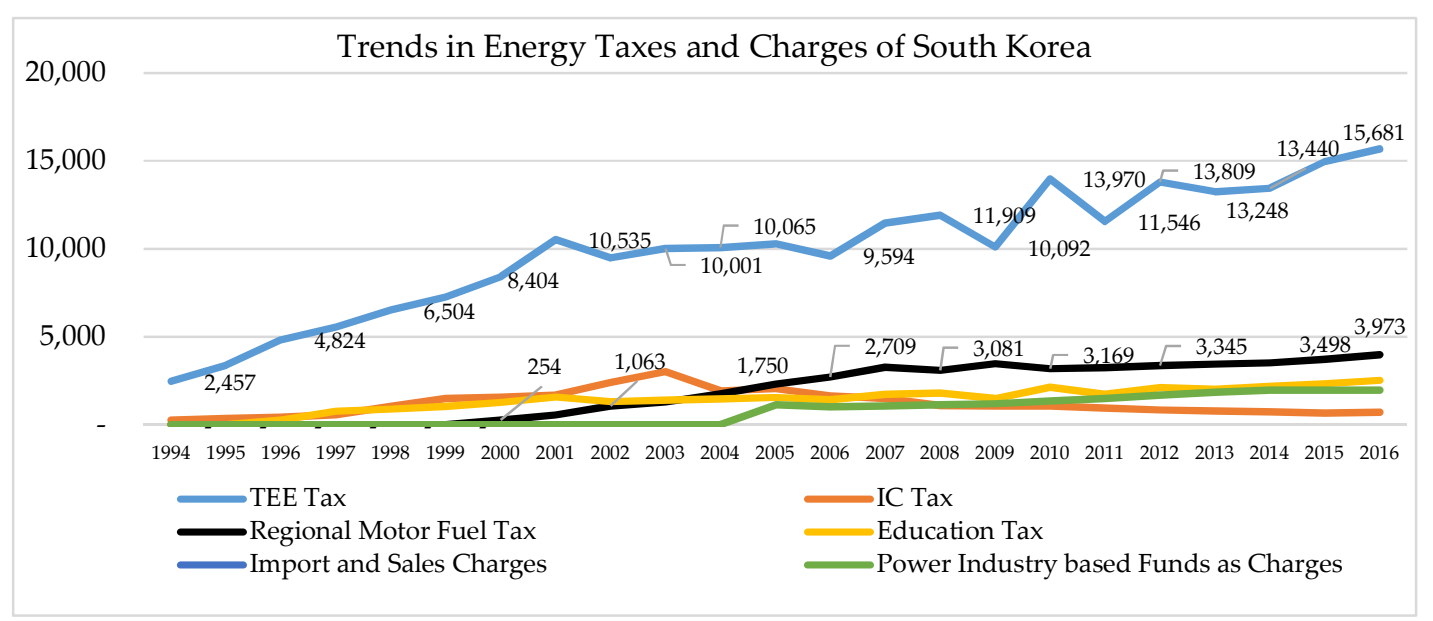

Figure 3. Trends in Energy Taxes and Charges of South Korea.

In addition, specific taxes and charges, such as TEE, driving, education, import, and sales taxes, excluding IC tax, constitute approximately $97 \%$ of the total energy tax revenues (Figure 4 ). Hence, the government must spend money to meet the original or specific purpose of energy taxation and be efficient in reducing energy or environmental pollution.

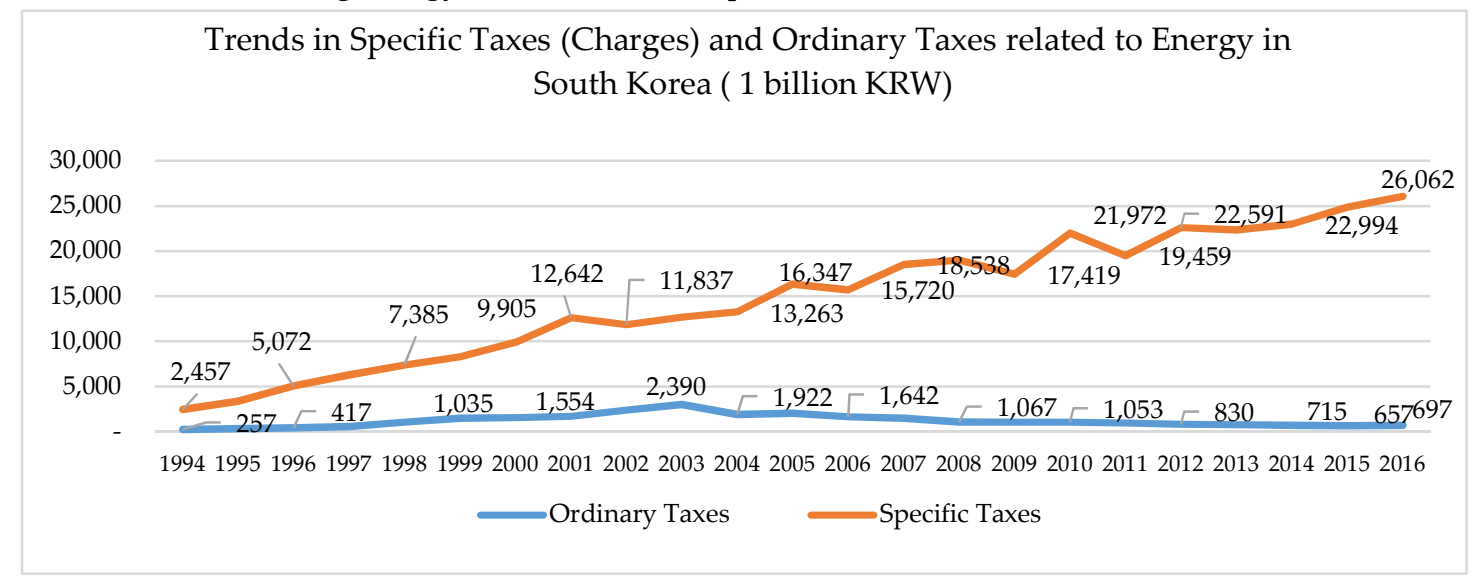

Figure 4. Trends in Specific Taxes (Charges) and Ordinary Taxes related to Energy in South Korea.

However, in terms of use and distribution, TEE tax has been used as a direct source of energy-related business until 2013. In 2018, TEE tax was used for non-directly related environmental and energy investment purposes, with $80 \%$ for traffic facilities, $15 \%$ for environmental improvements, $2 \%$ for regional development, and $3 \%$ for general purposes. This practice can be assessed as further usage of energy rather than as an intrinsic corrective function for energy taxation. For example, traffic facilities, environmental improvements, and regional development purposes are factors that increase the use of energy by entailing road traffic and construction.

Recently, South Korea's Board of Audit and Inspection recommended that the Ministries of Strategy and Finance, Land and Transport, Maritime Affairs, and Environment consult with one another to adjust the allocation ratio rationally for the use of the TEE tax to utilize related resources efficiently [20]. However, the Ministry of Land and Transport was somewhat negative, stating that it was a temporary phenomenon caused by the absence of large businesses in recent years. In addition, the Ministry of Environment responded that allocating resources for the TEE tax to meet 
the social costs of each sector would be reasonable. In addition, the Ministry of Strategy and Finance agreed with the recommendation of the Board of Audit and Inspection to review the allocation ratio adjustment.

\subsection{Flexibility}

South Korea's energy taxation is subject to flexible tax rates according to the government's energy policy. The government can change the tax rate for gasoline and diesel oil within $30 \%$ of the basic tax rate, if necessary, for the efficient operation of the national economy (e.g., expansion of traffic facilities and public transportation, energy- and resource-related projects, environment conservation and improvement projects, and support projects for oil price fluctuations).

In addition, the government can change the tax rate within $30 \%$ of the basic tax rate due to oil price fluctuations for kerosene, LPG, and bituminous coal, if necessary, to control the economy, stabilize prices, adjust supply and demand, and finance support projects.

To date, South Korea has had three tax rate changes in accordance with this flexible tax rate regulation. After the IMF control period in 2000, gasoline and diesel were cut by $5 \%$ and $12 \%$, respectively. In 2008, immediately after the global financial crisis, gasoline and diesel were cut by $10 \%$ for 10 months. In 2018, the tax rate was cut by $15 \%$ to activate the national economy for six months. Applying flexible tax rates to energy for flexible responses to macroeconomic environment changes contributes to desirable energy taxation.

\subsection{Accountability}

The current energy tax is vulnerable to accountability because it is an indirect taxation method, in which who is being taxed and how much is being taxed are unknown. In addition, measuring the actual energy tax burden of each income class is difficult due to the indirect taxation system of the complex structure. Therefore, a problem occurs where reliable statistical data are not provided periodically. Particularly, taxes and charges of energy-related consumption taxes for transportation, such as gasoline and light oil, are not displayed in tax invoices issued at the energy-purchasing stage. Thus, the actual transaction between the gas station industry and consumers is unclear.

The government should reliably measure the level of actual burden between energy sources for energy use and income groups. Thus, the government can persuade and gain the support of the low-income class by comparing the magnitude of the increased tax burden of environmental policy and its expected benefits. In South Korea's general 2019 tax reform, tax burdens increased by 7.9 billion KRW for high-income earners and large corporations and decreased by 3.2 billion KRW for low- and middle-income earners and small- and medium-sized enterprises. However, no tax incidences or shifting effects exist at this level in the case of energy tax reform.

\section{Suggestions for Rational Energy Taxation in South Korea}

\subsection{Simplicity of Energy Taxation}

The complexity of the current energy tax structure should be considerably simplified by integrating it into the IC tax to enhance the vertical equity of the energy tax burden and efficiently utilize the collected tax revenues. South Korea has the highest proportion of energy tax revenues with the strongest inverse of income, which suggests that energy tax equity must be improved. In addition to the structural features of the current energy taxation, which is composed of a large number of taxes and charges and a high percentage of specific taxes (e.g., TEE tax), energy taxation experiences the pressures of tax increases to meet the financial expansion needs of the government. Therefore, energy taxation is highly likely to be rigid and inefficient due to the strictness of tax use.

The simplification of the taxation system will lower the compliance costs of taxpayers and the expansion of general government finances through the abolition of specific taxes, thereby possibly improving the efficiency of public financial operations and alleviating the energy tax burden on 
taxpayers. If integrating the IC tax in a short term is difficult, then the IC tax will switch starting from the energy tax increase in the following year. In 1992, the Netherlands increased its financial efficiency by converting general fuel charges for specific purposes into general fuel taxes, which was managed by the Ministry of Finance.

\subsection{Flexibility of Energy Taxation}

South Korea has an extremely high proportion of energy tax revenue compared with the total tax revenue. The corrective function is strengthened by adjusting the relative tax rate between energy sources in the framework of maintaining the total amount of energy tax unless a national consensus on the necessity of total tax increase exists through energy tax increase. Moreover, the possibility of increased tax revenues must be avoided for corrective function inefficiency by allowing the need for increased public finance revenue based on objective logic and evidence.

If the energy tax is centered on the environmental tax function that internalizes social external costs, then the burden on the public may increase without decreasing the consumption of tobacco as in the case of the tobacco tax rate increase. South Korea currently has a flexible tax rate system; however, the system is ineffective because it defines the case where it can be used effectively as "efficient operation of the national economy." The elasticity of the energy tax system must be enhanced to maintain current energy tax revenues and achieve policy goals, such as price stabilization. This enhancement can be achieved by introducing an "automatic elasticity tax system" that automatically changes the flexible tax rate without revising the tax law.

These reforms in South Korea can also improve the political accountability of energy taxes on revenue and expenditure. In the Netherlands, the regulatory energy tax, which is an environmental tax created in 1996, increased tax revenues by reducing other taxes, such as social security contributions, earned income taxes, and corporation taxes, to minimize the adverse impact on competitiveness and equity of income redistribution.

\subsection{Direction of Energy Taxation for Power Generation and Transportation}

South Korea's energy tax reform has been reorganized as transportation fuel (oil). However, given that the tax level for energy for power generation is low, taxation on energy for power generation must be strengthened to eliminate the imbalance of the energy taxation system concentrated on transportation.

The state of energy for power generation to account for more than $55 \%$ of the total energy use while transportation energy, which accounts for only $15 \%$ of the total energy, accounts for more than $80 \%$ of the total energy tax revenue is uncommon. The government needs to reduce the tax burden on transportation energy and increase the tax burden on energy for power generation. In this case, tax burden adjustment should be increased to the level that can maximize the equity of energy tax burden between income groups, and increasing IC tax it is likewise desirable. To make such improvements, a reliable periodic measurement method for the level of taxation by income level of energy tax burden should be prepared.

In addition, public health risks caused by particulate matters have become a social issue, and the tax rates of transportation diesel should be raised to lower the social cost related to it. Transportation diesel is the main cause of particulate matter, and the relative price increase through taxes will significantly reduce the demand for diesel as transportation fuel.

However, to maintain the current energy tax revenue size, revising the IC and TEE taxes is desirable to increase the tax burden on diesel while simultaneously lowering it on energy sources, such as gasoline, which are relatively weak in tax equality. Meanwhile, taxpayers will likely continue to use diesel vehicles to some extent despite the tax increase on diesel. Thus, imposing environmental taxes on the basis of pollutant emissions is reasonable to because pollutant emissions differ depending on vehicles. 
However, a tax equality problem may occur by taxing "road infrastructure use contributions" through the TEE tax for internal combustion engine vehicles, which use oil as an energy source, and by exempting electric vehicles. Moreover, tax revenues can be reduced when an electric vehicle is replaced with an internal combustion engine vehicle. When energy tax revenues for transportation are mainly used for the construction and management of road infrastructure, electric or hydrogen cars using the same roads experience equity problems, such that riding without taxes on energy use is unfair. At the same time, a need to provide additional benefits (subsidies) for electric and hydrogen cars is plausible.

In view of the aforementioned scenarios, most of the energy tax for transportation has a structural characteristic composed of a specific tax. Given that the current transportation energy taxation follows a rigid specific tax scheme, establishing or expanding taxable objects is procedurally complex and difficult and requires a causal relationship between revenue and expenditure. Imposing an ordinary tax, such as IC tax, is desirable on all energy sources in common and to exempt temporarily or exempt specific energy sources for political purposes pursuant to a politically agreed policy objective.

\section{Discussion and Conclusions}

In Various policy instruments have been used to reduce GHG emissions globally. Among which, energy taxation is an important policy utilized in the majority of countries. It has a corrective function that reduces energy use or increases the production or use of environmentally friendly energy.

Particularly, in energy policy, South Korea depends entirely on imports of oil; thus, it is sensitive to the global energy situation, and the energy tax policy changes every year to reflect the domestic economic situation. In addition, the tax burden on energy use has increased annually because of the reduction of GHG and the balance between energy sources. A faithful reflection of the tax principles is necessary for energy tax on the basis of the energy policy of Korea to have high acceptance from people.

Therefore, this study evaluated the current energy taxation in South Korea from the viewpoint of tax principles, namely, equity, efficiency, simplicity, flexibility, and accountability. The results of this study are as follows. First, South Korea's energy tax revenue is higher than other taxes and higher than those of OECD member countries. Particularly, energy tax for residential sectors showed a regressive behavior depending on income level. Therefore, South Korea's energy taxation has a poor level of equity. Second, energy taxation in South Korea differs among energy sources on the basis of the country's energy policy principles. The tax burden on coal is relatively heavy to reduce GHG emissions and convert it into green energy. Therefore, energy taxation is positive in terms of efficiency.

Third, the country's energy taxation is composed of six taxes and five charges for energy use (e.g., transportation and power generation) and energy source (e.g., oil, coal, and gas). In addition, taxes consist of national and local taxes and are divided into ordinary and specific tax. Energy taxation is more complicated than other taxation. Therefore, South Korea's energy taxation is considered negative in terms of simplicity. Fourth, South Korea's energy policy is more sensitive to international energy policy and economic situation compared with other countries. Thus, its energy taxation operates a flexible tax rate system to respond flexibly to changes in global oil prices and economic conditions. This flexible tax rate was implemented in the periods of IMF management and global financial crisis. Therefore, energy taxation in South Korea is considered positive in terms of flexibility. Fifth, given that South Korea's energy taxation is an indirect tax, a high level of political accountability is required to support taxpayers and minimize tax resistance. Therefore, a reliable measurement process is important for the impact on energy tax. Thus, South Korea's energy taxation is considered to be negative in terms of accountability. 
On the basis of these evaluation results, this study suggests the following approaches to improve South Korea's energy taxation. First, the current energy taxation should be simplified. The current system consists of various taxes and charges; thus, simplifying the process of integrating the IC tax is necessary. Particularly, the use of energy tax revenue can solve the problem that the tax is not used for a specific purpose and reduce the compliance costs of taxpayers, given that the current energy tax is composed of specific and ordinary tax. Second, the level of flexibility of current energy taxation should be increased. This approach can solve the problem of inefficiency in which the energy tax revenue is higher compared with other tax revenues or the corrective function does not work. It can also solve the problem of inverse nature and increase political accountability. Third, the tax burden on environmentally friendly transportation energy must be reduced, whereas the tax burden for electric power generation fuels must be increased. Energy tax is directly linked to GHG reduction, which should increase the proportion of eco-friendly energy use. Thus, efficiency of energy taxation can be increased.

This study evaluates South Korea's energy taxation in terms of tax principles and suggests directions for improvement. On the basis of the results, if energy taxation is reformed, then such reform contributes to each energy use by the government and to balance by energy source. Therefore, this study provides policy implications on the direction of the South Korean government's energy policy and energy taxation.

Author Contributions: All authors participated in designing and writing the experiments, and performed the experiments and analyzed the data.

Conflicts of Interest: The authors declare no conflict of interest.

\section{References}

1. Wen, Wei; Li, Haowei; Yi, Fang. (2018). Thoughts on the Conversion of New and Old Kinetic Energy. Advances in Social Science, Education and Humanities Research, volume 246. 429-432. https://doi.org/10.2991/icpel-18.2018.99

2. Korea Economic Research Institute. (2017). Survey on public perception of energy conversion policy. VIP report 17-35(Vol. 708). (in Korean)

3. Yoo Seung-Hoon. (2018). The need for energy tax reform for power generation and the LNG tax rate. SNUT. (in Korean)

4. Kang M. O.; Shin S. C.; Kim Y. A. (2015). Environment Friendly Reform of Energy Tax and Establishment of Sustainable Energy Budget System in Korea. Korea Environment Institute.

5. Von Weizsäcker, E.U.; Jesinghaus, J. Ecological tax reform. In Ernst Ulrich von Weizsäcker. A Pioneer on Environmental, Climate and Energy Policies; vonWeizsäcker, E.U., Ed.; Springer: Heidelberg, Germany, 2014.

6. Marian Zaharia; Aurelia Patrascu; Manuela Rodica Gogonea; Ana Tanasescu; Constanta Popescu. (2017). A Cluster Design on the Influence of Energy Taxation in Shaping the New EU-28 Economic Paradigm. Energies 2017, 10, 257; doi:10.3390/en10020257

7. Burgers I. J., and S. E., Weishaar. (2018). Designing carbon taxes is not an easy task: Legal perspectives. WIFO Working Papers 559. https://www.econstor.eu/handle/10419/179313.

8. Kim Kap Soon; S-H, Yoo; Y. M., Koo; S. M., Yoon. (2018). Study on The Direction of The Energy Taxation Amendment. (in Korean)

9. José M. Labeaga; Xavier Labandeira; Xiral López-Otero. (2018). "Energy Tax Reform and Poverty Alleviation in Mexico," Working Papers 1801, Universidade de Vigo, Departamento de Economía Aplicada. https://ideas.repec.org/p/vig/wpaper/1801.html

10. Rausch, S.; Metcalf, G. E.; Reilly, J. M. (2011). Distributional impacts of carbon pricing: A general equilibrium approach with micro-data for households. Energy Economics, 33, Supplement 1, S20-S33.

11. Fullerton, D. (2011). Six Distributional Effects of Environmental Policy: Six Distributional Effects of Environmental Policy. Risk Analysis, 31(6), 923-929.

12. Williams, R. C.; III, Gordon, H.; Burtraw, D.; Carbone, J. C.; Morgenstern, R. D. (2015, March). The initial incidence of a carbon tax across income groups. National Tax Journal, 68(1), 195+. 
13. William A. Pizer; Steven Sexton. (2017). "Distributional Impacts of Energy Taxes," NBER Working Papers 23318, National Bureau of Economic Research, Inc.

14. Adam Smith. An Inquiry into the Nature and Causes of the Wealth of Nations (ed 1993).

15. Romano C. (2002), Advance Tax Rulings and Principles of Law Towards a European Tax Rulings System?, IBFD, Amsterdam, 281-384.

16. Alley Clinton; Duncan Bentley. (2005). A Remodelling of Adam Smith's Tax Design Principles. Australian Tax Forum

20.

579-624.

https://heinonline.org/HOL/LandingPage?handle=hein.journals/austraxrum20\&div=19\&id=\&page=

17. Tae Heon Kim. Study on improvement of CNG fuel taxation, Korea Energy Economics Institute, 2015. (in Korean)

18. Ministry of Trade, Industry and Energy in Korea. Energy budget and finalization of 2nd energy basic plan. (in Korean)

19. Flues, F.; A. Thomas. "The Distributional Effects of Energy Taxes," OECD Taxation Working Papers, No. 23, OECD Publishing, Paris, 2015. (http://dx.doi.org/10.1787/5js1qwkqqrbv-en)

20. 20. The Board of Audit and Inspection of KOREA. May 10, 2018. Details of audit by the Board of Audit and Inspection for the unreasonable allocation standard of transportation, energy, and environmental taxes by special accounts. (in Korean) 